\title{
SURFACE ELECTROMYOGRAPHY: PROPOSAL OF A PROTOCOL FOR CERVICAL MUSCLES
}

\author{
Eletromiografia de superfície: \\ proposta de um protocolo para músculos cervicais
}

\author{
Klyvia Juliana Rocha de Moraes (1), Daniele Andrade da Cunha ${ }^{(2)}$, \\ Luciana Ângelo Bezerra ${ }^{(3)}$, Renata Andrade da Cunha ${ }^{(4)}$, Hilton Justino da Silva ${ }^{(5)}$
}

\begin{abstract}
Purpose: to present a proposal of a surface electromyography evaluation method for cervical muscles specific and detailed protocol, with a standardized collection method of electrical signal in these muscles. Method: the researchers took as reference the existing publications about this subject which evidenced a need for standardization, clarity, better reproducibility and greater specificity for the surface electromyography evaluation of the upper trapezium and sternocleidomastoid muscles fibers. The proposal preparation process for the current protocol included the cleaning of the target area, placing the electrodes, required tasks in order to collect and register the electrical signal and interpretation of the electromyography signal parameters. This evaluation method was carried out in 24 healthy volunteers of both genders, with an average age of 26 years. We used the electromyography Miotool 400 with 4 channels. Result: an evaluation surface electromyography method for upper trapezium and sternocleidomastoid muscles fibers was developed and tested in order to determine the best form of electrical signal data collection for these muscles. Conclusion: we submitted a protocol proposal to evaluate the cervical muscles by a surface electromyography, allowing the healthy professionals and researchers to get more information about this electrical potential evaluation method for the sternocleidomastoid and the upper trapezium muscles fibers. This knowledge will be an adjuvant in a more specific therapy.
\end{abstract}

KEYWORDS: Electromyography; Electrodes; Site Selection; Electric Impedance

(1) Physiotherapist; Preceptor Internship in Physical Therapy from the University Salgado de Oliveira, Federal University of Pernambuco, UFPE, Recife- PE, Brazil; Master of Pathology from Federal University of Pernambuco -UFPE.

(2) Speech Therapist; Coordinator Course of Speech in Faculdade Integrada of Recife, Faculdade Integrada of Recife, FIR, Recife- PE, Brazil; PhD in Nutrition from Federal University of Pernambuco -UFPE.

(3) Physiotherapist; Physiotherapist Clinic Pepita Duran, Recife-PE, Brazil; Specialist in Cardiorespiratory Physical Therapy from the Gama Filho University - UGF.

(4) Physiotherapist; Physiotherapist Neurofunctional home, Recife-PE, Brazil; Specialist in Neurofunctional Physical Therapy from Faculdade Integrada of Recife -FIR.

(5) SpeechTherapist; Vice-Coordinator of the post-graduate studies in Pathology, Master level, Professor of Speech Pathology course at the Federal University of Pernambuco - UFPE, Federal University of Pernambuco - UFPE, Recife-PE, Brazil; PhD in Nutrition from Federal University of Pernambuco -UFPE.

Conflict of interest: non-existent

\section{INTRODUCTION}

The Stomatognathic System is described in the literature as a functional unit of human body comprising components of the body skeletal, dental arch, muscles and other structures, bringing a close relationship with cervical muscles ${ }^{1}$.

The literature shows the myofascial tissue as an inseparable functional entity. The occurrence of muscular synergism justifies the interdependence of muscle tissue as well as a continuity of solution ${ }^{1}$ that reveals the occurrence of disturbances which follow muscular chains ${ }^{1,2}$.

Campignion ${ }^{3}$ suggested that the voluntary action of the cervical muscles, represented by the upper trapezius fibers and sternocleidomastoid muscles could be facilitated by the action of the cervical 
muscle group, resulting in greater coordination of movement, proximal stabilization and functional gain in the same region. The evaluation of skeletal cervical muscle, has important value because the influence of posture and stress on the musculoskeletal changes is a primary overload commonly observed ${ }^{4}$.

Researchers have shown that the disorders of the cervical muscles are a serious and frequent problem that interest in developing standards for adequate muscular evaluation, in multidisciplinary teams, in order to minimize or prevent such problem ${ }^{5}$.

There are published reports that the postural control of head and neck depends on the integration of the sternocleidomastoid and upper trapezius fibers muscles, controlling the gravitational torque, influencing the functionality of the cervical region ${ }^{6}$.

A practical way to clinically investigate the musculoskeletal conditions, particularly in the cervical muscles ${ }^{7}$ and verify their physiological conditions $^{8}$, with regard to action, is the Surface Electromyography (sEMG) ${ }^{8-11}$.

This monitoring can be used as a safe, easy and noninvasive method ${ }^{9,10}$ to measure the electrical muscle activity during function ${ }^{9}$, in addition to being used as an auxiliary to the study of muscle kinesiology ${ }^{12}$. A study by Ericson and Fernstrom ${ }^{13}$ examined how the electrical activity of upper fibers of trapezius muscle changed during the modification of the activity.

Therefore, there is a great importance for the knowledge on in vivo muscle physiology, in the differential diagnosis and monitoring of possible disorders. Knowing what is normal, can help the diagnosis with conditions that they are abnormal ${ }^{14}$ and may provide a more thorough and reliable of patient outcomes and the effectiveness of therapy applied ${ }^{15}$.

Some researches indicated the need of a standardization of the collection of EMG data in order to have more reliable recordings ${ }^{9,16}$. There are some reports in the literature regarding the methodological difficulties of sEMG recordings, describing some limitations such as flaws in research protocols by the difficulty in reproducing the positioning of the electrodes, as well as a lack of more specific protocols ${ }^{16}$.

The regulatory standards for EMG decision, analysis, interpretation and the records of signs have been a concern to the implementers of this technique. They present as a solution, the preparation of a practical guide that aims to standardize the procedures in the electromyographic studies ${ }^{17,18}$.

The researchers took as reference the existing publications about the proposed subject $t^{7,9,17,18,22,24,27}$ which identified a need for standardization, greater reproducibility ${ }^{17,19}$, clarity and specificity to evaluate the sternocleydomastoid ${ }^{22}$ and upper trapezius fibers.

Thus, the objective of this paper is to present a proposal of protocol for SEMG evaluation for cervical muscles specific and detailed in an attempt to standardize these results, contributing to the standardization of tests by different professionals, collaborating with the academic background of students in the health area and favoring the comparison of findings from different study centers.

\section{METHOD}

During the 2009 and 2010 years, a multidisciplinary group of Brazilian researchers in electromyography with extensive experience in research and clinical area, met periodically to discuss the needs of a specific protocol for sEMG analysis of cervical muscles, more precisely, to the Sternocleidomastoid muscle (SCM), and upper fibers of trapezius muscle.

The process of elaboration the current proposal of protocol included the skin cleaning, the electrodes placement position, tasks required to collect the electrical signal and parameters to be collect from the electromyographic signal.

The data of muscle electrical potential were collected by the electromyography equipment (Miotool 400) connected to the LG notebook with Windows ${ }^{\circledR}$ Vista Premium operating system with 110GB HD, Intel ${ }^{\circledR}$ Dual-Core Processor $1.60 \mathrm{GHz}, 2$ GB of RAM, 32 BITs, with the Miograph 2.0 software.

The electromyography showed up with a gain of 1000; 4 sensors SDS500 with grab type terminals; 1 ground cable all MIOTEC ${ }^{\circledR}$ brand and 1 USB communication cable to capture the electrical potential of SCM fibers and upper fibers of trapezius muscles, bilaterally. Bipolar surface EMG electrodes were used (Ag/AgCl electrodes - Tyco Helthcare, Meditrace 100-Kendall) with conductive gel and properly secured with $3 \mathrm{M}^{\mathrm{TM}}$ Micropore ${ }^{\mathrm{TM}}$ Tape.

The researchers applied this proposal of protocol in the laboratory of electromyography of the Pathophysiology of the Stomatognathic System research group on the Campus of the Federal University of Pernambuco (UFPE) in 24 volunteers of both genders with the mean age of 26 years, to verify its reproducibility as well as investigating the best maneuver that would generate the best electromyographic signal to the evaluated muscle.

All volunteers were students of Federal University of Pernambuco (UFPE), chosen randomly, with no complaints of pain in the cervical region or shoulders, and they were not under treatment for postural changes or claw. The cervical region 
was assessed by photographic recording (digital photogrammetry), in anterior view, right lateral view, left lateral view and posterior view, in order to position the cervical region for electromyographic evaluation. All these evaluations were performed in the morning, according to the circadian cycle. All volunteers signed an informed consent term about the research, keeping a copy of it with them.

During the electromyography evaluation, environmental noise was controlled closing doors and windows and turning off the air conditioning to make the room more appropriate for the collection. This research was approved by the Ethics Committee and Research of the Cancer Hospital of Pernambuco (CEP/HCP), under protocol no 41/2009.

\section{RESULTS}

Figure 1 shows the phases of protocol of the electromyographic evaluation for the SCM and upper fibers of trapezius muscles.

\section{DISCUSSION}

The protocol presented in this paper was prepared to have the largest contingent of possible information at the time of electromyographic evaluation, facilitating its reproduction. It is simple and easily applied which encourages future studies.

The skin of the muscles evaluated was cleaned with cotton and alcohol $70 \%$, as well as the lateral epicondyle region of the right humerus, according to the recommendations of Surface Electromyography for the Non-Invasive Assessment of MusclesSENIAM $^{19}$. This region was slightly scorched in the direction of SCM and upper fibers of trapezius muscles. The literature reports that the skin cleaning aims to reduce the impedance and eliminates any interference from the electrical signal ${ }^{20,21}$.

To find the muscle belly, the concentric contraction for each studied muscle was requested, as reference, based on Falla et al. ${ }^{7}$ and from this, followed by placing the electrodes. For each SCM muscle, the electrodes were fixed at the midpoint of the muscle belly along its fibers ${ }^{7,18,19}, 4 \mathrm{~cm}$ below the insertion on the mastoid process (one channel for each SCM muscle) with the patient at rest ${ }^{22}$. This distance of $4 \mathrm{~cm}$ is suggested to avoid interference in the electrical signal by the fibers of the platysma muscle ${ }^{22}$. These interferences has been described by some researchers as the crosstalk phenomenon ${ }^{7,9,11,23-25}$, which captures the electrical signal from adjacent muscles and could interfere in the evaluated signal ${ }^{7,11}$.

Researches also indicate the size of the electrode because the larger the size, the greater the amplitude of electrical signal, however, strengthen the possibility of the effect crosstalk from other muscles ${ }^{19,26}$. Thus, the choice of ideal electrode, location and interelectrode distance will be mechanisms to minimize this effect ${ }^{7,11}$.

In the current protocol, the choice of small electrode size was standardized to fit well to the studied muscles, self-adhesive and interelectrode distance of $1.5 \mathrm{~cm}$ according to guidelines published by International Society of electrophysiology and Kinesiology-ISEK/Surface Electromyography for the NonInvasive Assessment of Muscles-SENIAM ${ }^{11,19,27}$.

Researchers report the electrode placement should be in the motor point of the muscle belly where it will include the Innervation Zones (IZ) located along the muscle fiber near the midpoint of the muscle belly to optimize the accuracy of the electrical signal and to portray a character of greater reproducibility of the sEMG technique ${ }^{7}$. Merletti et al. ${ }^{28}$ report that the differences in sEMG signals may arise from changes in the IZ location of the muscles, emphasizing the need to respect them.

For the upper fibers of each trapezius muscle, the electrodes were placed at half the distance between the acromion line and seventh cervical vertebra of the spine $(\mathrm{C} 7)^{27}$, longitudinal fibers (1 channel for each upper fibers of trapezius muscle) $)^{27,29}$. The ground electrode was placed over the right humerus lateral epicondyle to reduce interpositions of external electrical noise.

The actions that represented the best collection of SEMG record of the muscles studied were based on muscle function testing ${ }^{15}$ to know: the cervical flexion-rotation to the right (manually resisted) and cervical flexion-rotation to the left (manually resisted), for the increased the activation of SCM muscle. For the increased the activation of upper fibers of trapezius muscle, elevation of both shoulders, simultaneously (manually resisted). These actions were taken as a basis for normalization of SEMG signal and to proposed activities, being named Maximum Resistive Voluntary Activity $\left(\mathrm{M}_{\mathrm{AVR}}\right)$. Thus, for the SCM muscle, is determined the $\mathrm{M}_{\mathrm{AVR}}$ to the right SCM $\left(M_{A V R}\right.$ of the $\left.\mathrm{SCM}_{\mathrm{R}}\right)$; to th left SCM $\left.\left(M_{A V R} \text { of the SCM }\right)_{L}\right)$; and to the upper fibers of right and left trapezius $\left(M_{A V R}\right.$ of the $U_{T F}$ and $\mathrm{M}_{\mathrm{AVR}}$ of the $U T F_{L}$ ).

The normalization process of sEMG signal was based on ISEK ${ }^{19}$. However, the Maximum Activity Voluntary Resistive $\left(M_{A V R}\right)$ with manual loading was availed instead of considering the Maximum Voluntary Isometric Contraction (MVIC) with a known load and mensurable.

For manual resistance imposed, there is no the possibility of measuring the same, however, to be attributed to $M_{A V R}$ for the normalization sEMG the 


\begin{tabular}{|c|c|}
\hline Phase 1 & $\begin{array}{l}\text { Preparation for the Test: } \\
\text { - Volunteer position: Sitting in a chair, with feet flat on the ground, arms relaxed and looking forward } \\
\text { directed. } \\
\text { - The location area of SCM, upper trapezius fibers muscles (bilaterally) and right humerus lateral } \\
\text { epicondyle must be cleaned with cotton and alcohol } 70 \% \text {. }\end{array}$ \\
\hline Phase 2 & $\begin{array}{l}\text { Electrodes placement position: } \\
\text { - Volunteer position: The same as the previous phase. } \\
\text { - Reference electrode in right humerus lateral epicondyle of the volunteer to minimize interference } \\
\text { from external electrical noise. } \\
\text { - Pick-up electrode fixed at the midpoint of the } S C M, 4 \mathrm{~cm} \text { from the mastoid process, along the muscle } \\
\text { fibers (bilaterally).* } \\
\text { - Pick-up electrode in the upper fibers of trapezius muscle at half the distance between the acromion } \\
\text { line and C7, along the muscle fibers (bilaterally). }{ }^{*} \\
\text { - Interelectrode distance of } 1,5 \mathrm{~cm} \text {. } \\
\text { - } 4 \text { channels enabled in the electromyograph where the odds were agreed to the left side and the } \\
\text { pairs to the right.** }\end{array}$ \\
\hline Phase 3 & $\begin{array}{l}\text { Normalization Signal: Maximum Activity Voluntary Resisted }\left(M_{A V R}\right) \\
\text { - Volunteer position: Voluntary standing, usual and comfortable posture, without shoes or socks, men } \\
\text { without shirt or women dressing a top, looking to the horizon, with the upper limbs along the body } \\
\text { (relaxed) without see the computer screen to avoid the visual feedback and commitment evaluation. } \\
-M_{A V R} \text { maintained for } 5 \text { seconds, of the cervical flexion-rotation toward the right shoulder (manually } \\
\text { resisted) for the increased the activation of } S C M\left(M_{A V R} \text { of the } S C M_{R}\right) \text {. } \\
\text { - } M_{A V R} \text { maintained for } 5 \text { seconds, of the cervical flexion-rotation toward the left shoulder (manually } \\
\text { resisted) for the increased the activation of SCM }\left(M_{A V R} \text { of the } S C M_{L}\right) \text {. } \\
-M_{A V R} \text { maintained for } 5 \text { seconds, of elevation of both shoulders simultaneously (manually resisted) for } \\
\text { the increased the activation of upper fibers of trapezius muscle }\left(M_{A V R} \text { of the UTF } F_{R} \text { and } M_{A V R} \text { of the }\right. \\
\left.\text { UTF }{ }_{L}\right) \text {. } \\
\text { Note: Perform once every } M_{A V R} \text { with intervals of } 10 \text { s between } M_{A V R} \text {. After completion it, wait a minute } \\
\text { to start the next stage. }\end{array}$ \\
\hline Phase 4 & 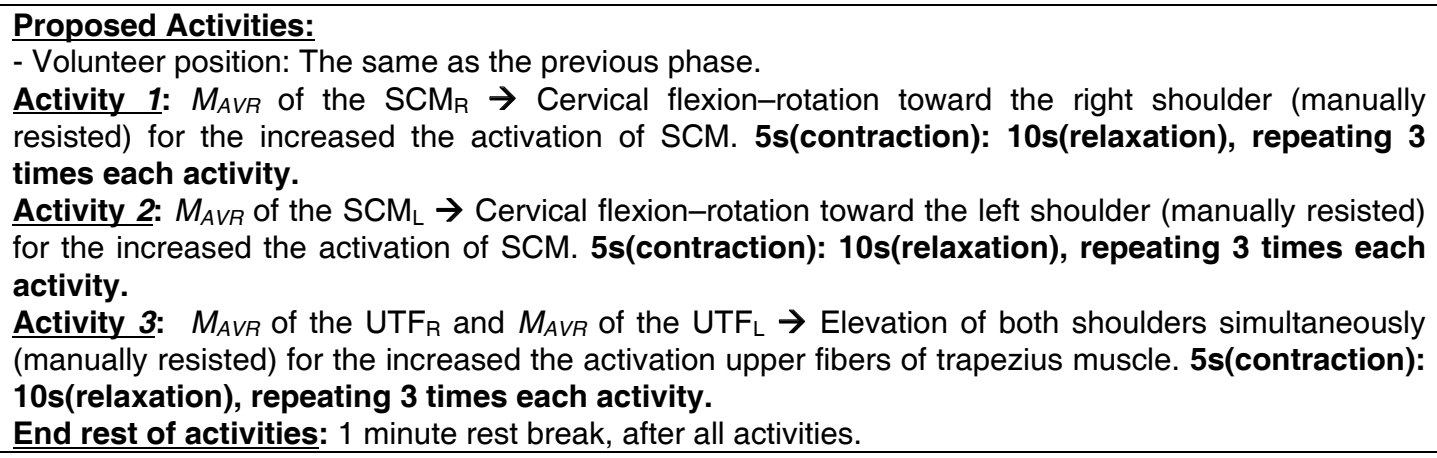 \\
\hline Phase 5 & 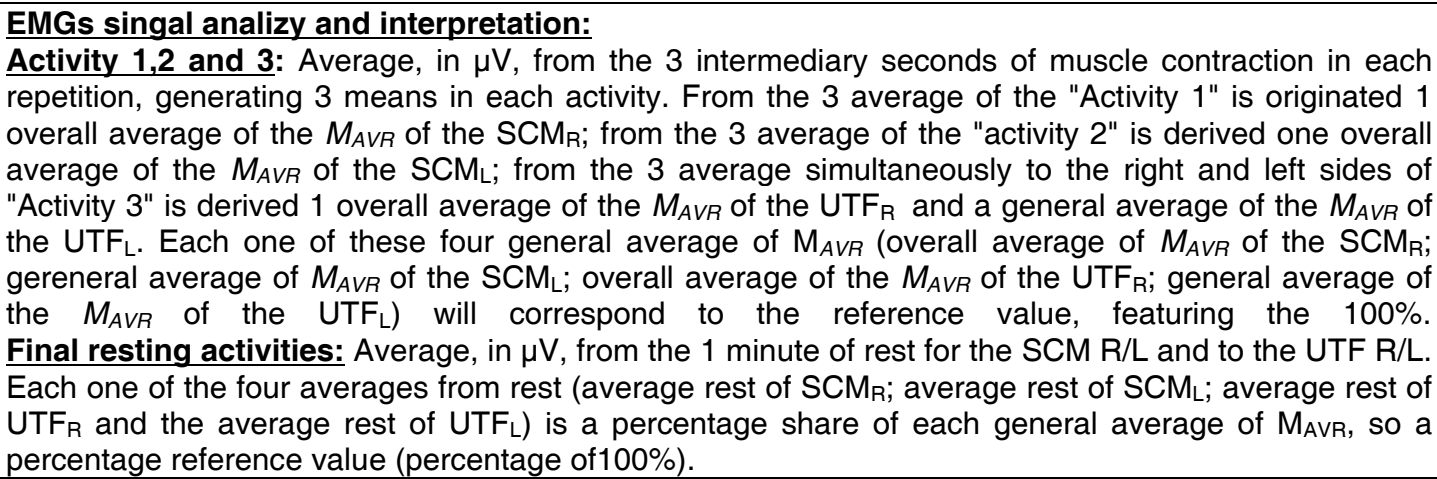 \\
\hline
\end{tabular}

* Bipolar surface EMG electrodes

** Channel 1 and 2 for the upper portion left and right trapezius muscle, respectively. Channel 3 and 4 for of left and right SCM muscle, respectively.

Figure 1 - Phases of protocol of the electromyographic evaluation for the SCM and upper trapezius fibers muscles 
examiners were aware of the signal spectral graph on the computer screen, imposed referring to maximum activity. Each of the $3 M_{A V R}$ for normalization lasted 5 seconds, interspersed by 10 seconds of rest between executions with only one repetition for each test.

Although there is a large contingency about the normalization of EMG signal from the MVIC ${ }^{19,25,30-33}$, the literature does not address the normalization form of sEMG signal with known and measurable loads, proposed by MVIC for the muscles evaluated in this protocol, nor not to the facial muscles, thus justifying the use of $M_{A V R}$.

After normalization, the implementation of activities proposed for the $\mathrm{SCM}\left(M_{A V R}\right.$ of the $\mathrm{SCM}_{\mathrm{R}} ; M_{A V R}$ of the $\mathrm{SCM}_{L}$; characterizing the 1 and 2 activities of the figure 1) and the upper trapezius fibers muscles $\left(M_{A V R}\right.$ of the UTF ${ }_{\mathrm{R}}$ and $M_{A V R}$ of the UTF $\mathrm{UT}_{\mathrm{L}}$; characterizing the 3 activity of the figure 1 ) were done. Each activity, differently the normalization, was repeated 3 times with 5 seconds of contraction for 10 seconds of relaxation (ratio 1:2), adapted from Barbosa and Gonçalves ${ }^{34}$ and Kakihara, Sens and Ferreira ${ }^{35}$, with 1 minute rest break at the end rest of the activities.

In EMGs signal interpretation the literature shows that the moment of major stabilization of the electromyographic signal is one who understands the middle region of this signal, so the intermediary seconds of each muscle contraction, represented in the signal spectrum EMGs ${ }^{36,37}$. Thus, the average in microvolts $(\mu \mathrm{V})$ of 3 intermediate seconds of muscle contraction, in each of the repetitions in the proposed activities, producing a single average for each activity (activities 1,2 and 3, referring to the general average of the $M_{A V R}$ of the $\mathrm{SCM}_{\mathrm{R}}$; overall average of the $M_{A V R}$ of the $S C M_{\mathrm{L}}$; overall average of the $M_{A V R}$ of the UTF ${ }_{R}$ and general average of the $M_{A V A}$ of the $U T F_{L}$ ) represent this stabilization moment of EMGs signal, which serves as the benchmark, so the $100 \%$ of activities.

The electric potential related to the final resting activities (end rest of $\mathrm{SCM}_{\mathrm{R}}$; end rest of $\mathrm{SCM}_{\mathrm{L}}$; end rest of $\mathrm{UFT}_{\mathrm{R}}$ and end rest of $U F T_{L}$ ), start to match a percentage share of the overall averages of $\mathrm{M}_{A V R}$, so a percentage of the reference value ${ }^{34,35}$. Being this the reference value the most stabilish moment of EMGs signal ${ }^{36,37}$.

\section{CONCLUSION}

This paper presented a proposal of protocol for sEMG evaluation for cervical muscles allowing more information about the evaluation of the electrical potential of SCM and upper fibers of trapezius muscles to physiotherapists, other health professionals and specialists. This knowledge will serve in specific adjuvant therapies.

It is suggested that more publications of protocols for other specific muscles happen to strengthen the technique as well as its reliable and universal reproduction in an attempt to minimize the possible biases and differences between evaluators.

\section{ACKNOWLEDGMENT}

The authors thank the National Council of Technological and Scientific Development (CNPq), which had a financial support with Edictal Universal MCT/ CNPq 14/2009 - Faixa B - Process: 476412/2009-9. 


\section{RESUMO}

Objetivo: apresentar uma proposta de avaliação da eletromiografia de superfície em músculos cervicais de forma específica e detalhada, com a finalidade de padronizar o método de coleta do sinal elétrico nesta musculatura. Método: os pesquisadores tomaram como referência as publicações já existentes, acerca do tema proposto, na qual foi evidenciada a necessidade de padronização, maior reprodutibilidade, clareza e maior especificidade para a avaliação eletromiográfica de superfície dos músculos esternocleidomastóideo e das fibras superiores do trapézio. O processo de elaboração da proposta do protocolo abrangeu a limpeza da região avaliada, a colocação e posicionamento dos eletrodos, as tarefas realizadas para a coleta do sinal elétrico, e os parâmetros a serem registrados e interpretados do sinal eletromiográfico. Este método de avaliação aplicou-se em 24 voluntários saudáveis de ambos os sexos, com média de idade em 26 anos, sendo utilizado o eletromiógrafo da marca Miotool 400 com 4 canais. Resultado: um método de avaliação eletromiográfico de superfície nos músculos esternocleidomastídeo e fibras superiores do trapézio foi elaborado, e testado para demonstrar a melhor forma de coleta do sinal elétrico para estes músculos. Conclusão: apresentamos uma proposta de protocolo para a avaliação da eletomiografia de superfície nos músculos cervicais, permitindo aos profissionais da saúde e estudiosos do tema, maiores informações sobre o método de avaliação do potencial elétrico dos músculos esternocleidomastóideo e das fibras superiores do trapézio. Estes conhecimentos servirão como coadjuvantes numa terapia mais específica.

DESCRITORES: Eletromiografia; Eletrodos; Seleção do Sítio; Impedância Elétrica

\section{REFERENCES}

1. Vázquez-Nava F, Vázquez REM, Saldivar GAH, Beltrán GFJ, Almeida AVM, Vázquez RCF. Allergic Rhinitis, Feeding and Oral Habits, Toothbrushing and Socioeconomic Status. Caries Res. 2008; 42:141-7.

2. Rydeard R, Leger A, Smith D. Pilates-based Therapeutic Exercise: Effect on Subjects with Nonspecific Chronic Low-back Pain and Functional Disability: a randomized controlled trial. J Orthop Sports Phys Ther. 2006;36(7):472-84.

3.Campignion P. Aspectos Biomecânicos, Cadeias Musculares e Articulares - método GDS. São Paulo: Summus, 2003.

4.Menoncin LCM, Jurkiewicz AL, Silvério KCA, Camargo PM, Wolff NMM. Alterações musculares e esqueléticas cervicais em mulheres disfônicas. Arq. Int. Otorrinolaringol. 2010; 14(4):461-6.

5. Mercer JA, Bezodis N, Delion D, Zachry $T$, Rubley MD. EMG sensor location: Does it influence the ability to detect differences in muscle contraction conditions? J Electromyogr Kinesiol. 2006;16:198-204.

6.Falla D, Farina D. Neuromuscular adaptation in experimental and clinical neck pain. J Electromyogr Kinesiol. 2008; 18:255-61.

7. Falla D, Dall'Alba $P$, Rainoldi A, Merletti R, Jull G. Location of innervation zones of sternocleidomastoid and scalene muscles- a basis for clinical and research electromyography applications. Clin Neurophysiol. 2002,113:57-63.

8.Malta J, Campolongo GD, Barros TEP, Oliveira RP. Eletromiografia aplicada aos músculos da mastigação. Acta Ortop Bras. 2006;14(2):106-7.

9. Moraes KJR, Cunha RA, Lins OG, Cunha DA, Silva HJ. Eletromiografia de superfície: padronização da técnica. Neurobiol. 2010; 73(3):151-8.

10. Bassani E, Candotti CT, Pasini M, Melo M, La Torre M. Avaliação da ativação neuromuscular em indivíduos com escoliose através da eletromiografia de superfície. Rev Bras de Fis. 2008;12(1):13-9.

11.Tank FF, Silva GT, Oliveira CG, Garcia MAC. Influência da distância intereletrodos e da cadência de movimento no domínio da frequência do sinal de EMG de superfície. Rev Bras Med Esporte. 2009; 15(4):272-6.

12. Amadio AC, Duarte M. Fundamentos biomecânicos para análise do

movimento. São Paulo: Laboratório de Biomecânica EEFUSP; 1996.

$162 p$.

13. Ericson MO, Fernstrom EA. Upper-Arm Elevation During Office Work. Ergonom. 1996;39(10):1221-30. 14. Veiga PHA. Análise eletromiográfica como base para o tratamento das luxações recidivas da patela. Fisioter em Mov. 2007;20(1):11-6.

15. Pereira TB, Bergmann A, Ribeiro ACP, Silva JG, Dias R, Ribeiro MJP, et al. Padrão da atividade mioelétrica dos músculos da cintura escapular após 
linfadenectomia axilar no câncer de mama. Rev Bras Ginecol Obstet. 2009;31(5):224-9.

16.Santiago JR. Análise do estudo eletromiográfico dos músculos estomatognáticos [dissertação]. Santos (Mestrado em Patofisiologia de Órgãos e Sistemas): Universidade Metropolitana de Santos; 2000, 94p.

17. Basmajlan JV, DeLuca CJ. Muscle alive: their function revealed by electromyography. 5th ed. 1985.

18. DeLuca CJ. The use of electromyography in biomechanics. J Biomech. 1997; 13:135-63.

19. Hermens JH, Freriks B, Klug CD, Rau G. Development of recommendations for SEMG sensors and sensor placement procedures. J Electromyogr Kinesiol. 2000; 14:361-74.

20. Barros, RML; Russomanno TG; Brenzikover $\mathrm{R}$, Figueroa PJ. A method to synchronise video cameras using the audio band. J Biomech. 2006; 39:776-80.

21. Santos GM, Say KG, Pulzato F, Oliveira AS, Bevilaqua-Grossi D, Monteiro-Pedro V. Relação eletromiográfica integrada dos músculos vasto medial oblíquo e vasto lateral longo na marcha em sujeitos com e sem síndrome de dor femoropatelar. Rev Bras Med Esporte. 2007; 13(1):17-21.

22. Costa D, Vitti M, Tosello DO. Electromyographic study of the sternocleidomastoid muscle in head movements. Electromyogr and clin neurophysiol. 1990;30(7):429-34.

23. Silva GT, Tank FF, Alves RB, Barbier LK, Oliveira CG, Garcia MAC. Influência da distância intereletrodos no domínio do tempo do sinal de EMG de superfície em contrações isotônicas do músculo bíceps braquial. Arq em Mov. 2008; 4(2):16-33.

24. Malek MH, Housh TJ, Coburn JW, Weir JP, Schmidt RJ, Beck TW. The effects of interelectrode distance on electromyographic amplitude and mean power frequency during incremental cycle ergometry. J Neurosci Methods. 2006;151:139-47.

25.Schwartz FP, Soares FA, Salomoni S, Rocha AF, Nascimento FAO, Romariz ARS. Análise de Filtros Espaciais em Sinais EMG de Superfície nas Condições do Máximo Volume de Contração. IFMBE Proceed. 2007;18:95-8.

http://dx.doi.org/10.1590/S1516-18462011005000133

RECEIVED ON: 01/27/2011

ACCEPTED ON: 05/08/2011

Mailing Address:

Klyvia Juliana Rocha de Moraes

Rua Hélio Falcão, 176, Apt 803

Boa Viagem - Recife/PE

CEP: 51021-070

E-mail: klyviaj@yahoo.com.br
26. Delsys (2010). Neuromuscular research center. Boston University [Acesso em 13 fev 2010]; Disponívem em: http:// www.delsys.com/library/ papers.

27. SENIAM (2010). "SENIAM: European Recommendations for Surface

Electromyography." [Acesso em: 13 fev 2010]; Disponível em: http:// www.seniam.org .

28. Merletti R, Rainoldi A, Farina D. Surface electromyography for non-invasive

characterization of muscle. Exerc Sport Sci Rev. 2001;29:20-5.

29.Kamom E, Gormley J. Muscular activity pattern for skilled performanced and during learning of a horizontal exercise. Ergonom. 1968;11:345- 57.

30.Bueno RC, Fortes JBP, Camacho SP. Eletromiografia do músculo quadríceps femural: influência do treinamento específico no disparo neuromotor periférico. Mov e Percep. 2007; 8(11):55-70.

31. Linnamo V, Strojnik V, and Komi P V. Maximal force during eccentric and isometric actions at different elbow angles. Eur J Appl Physiol. 2006; 96(6): 672-8.

32. Arruda ARC, Rosa RC, Freitas FS, Léo JA, Shimano AC, Bertoncello D. Elaboração de equipamentos para mensuração de força isométrica de punho e antebraço. ConS Saúde. 2008;7(1):61-7. 33. Vera-Garcia FJ, Moreside JM, McGill SM. MVC techniques to normalize trunk muscle EMG in healthy women. $\mathrm{J}$ of Electromyogr and Kinesiol. 2010;20:10-6.

34. Barbosa FSS, Gonçalves M. Protocolo para identificação da fadiga dos músculos eretores da espinha por meio da dinamometria e da eletromiografia. Fis em Mov. 2005; 18(4):77-87.

35. Kakihara CT, Sens YAS, Ferreira U . Effect of functional training for the pelvic floor muscles with or without electrical stimulation in cases of urinary incontinence following radical prostatectomy. Rev Bras Fisioter. 2007;11(6):481-6.

36. Ferrario VF, Tartaglia GM, Galletta A, Grassi GP, Sforza C. The influence of occlusion on jaw and neck muscle activity: a surface EMG study in healthy young adults. J of Oral Rehabil. 2006; 33: 341-8.

37. Ferrario VF, Tartaglia GM, Luraghi FE, Sforza C. The use of surface electromyography as a tool in differentiating temporomandibular disorders from neck disorders. Manual Therapy. 2007; 12: 372-9. 